\title{
The Genesis of Cell Types in the Adenohypophysis of the Human Fetus as Observed with Immunocytochemistry '
}

\author{
BURTON L. BAKER AND ROBERT B. JAFFE 2,3 \\ Department of Anatomy and Department of Obstetrics and Gynecology, \\ The University of Michigan Medical School, Ann Arbor, Michigan 48104
}

\begin{abstract}
Hypophyses of 21 human fetuses, ranging in gestational age from 6 to 23 weeks, were studied by immunocytochemical and histological staining to ascertain (1) the time of origin of specific cell types and (2) the development of parenchymal cell zonation in the pars distalis. No hormones were identified at six weeks. Probable corticotrophin-containing cells appeared at seven weeks. Somatotrophs were observed first at 10.5 weeks; correlation with other reports indicates that they appear at eight to nine weeks. Melanotrophs were detected at 14 weeks; the cells containing melanotrophin were far fewer than corticotrophs. The youngest fetus to possess gonadotrophs was 10.5 weeks old. In all specimens gonadotrophs (LH-cells) stained well with immunocytochemical procedures but poorly with histological methods. Thyrotrophs first occurred at 13 weeks.

Zonal distribution of cell types in the pars distalis was evident almost from the time of their appearance. Somatotrophs were most numerous laterally and immediately anterior to the residual cleft. At 10.5 weeks corticotrophs were confined chiefly to the borders of vascularized connective tissue (trabeculae) and to the lateral peripheral region of the pars distalis. Thyrotrophs appeared chiefly in the anteromedian zone, particularly in its superior portion, but were found laterally also. In the older specimens, gonadotrophs generally occurred throughout the pars distalis but were less numerous near the trabeculae and in the anterolateral region.

There was good correlation between the time of appearance of various cell types and published data on secretory capacity of the gland.
\end{abstract}

With increasing attention being given to the endocrinology of the human fetalplacental unit, a more precise understanding of the development of secretory competence by the fetal hypophysis is desirable. Particularly critical is determination of the earliest time at which each hormone is secreted by the adenohypophysis. Investigators have attacked this problem by using several technical methods, including assay for the presence of hormones in umbilical blood, in the pituitary gland itself, or in medium in which the gland has been cultured. Others have utilized staining procedures and immunofluorescence for demonstrating the time in gestation when specific cell types appear (table 1).

The study reported here is concerned with the genesis of specific cell types in the human fetal adenohypophysis as revealed by immunocytochemistry correlated with histological staining. ${ }^{4}$ The exceptional sensitivity and specificity of immunocytochemistry should enable one to ascertain with considerable accuracy the time when hormones first appear in the gland. Indeed, little is known about the development of corticotrophs, mammotrophs, and melanotrophs; evidence pertaining to the status of

\footnotetext{
Accepted January 17, '75.

1 Supported in part by research grants from the $\mathrm{Na}$ tional Institutes of Health, HD-03159-06 to Dr. B. L. Baker and HD-08478 to Dr. R. B. Jaffe.

${ }^{2}$ Dr. Jaffe's present address is: Reproductive Endocrinology Center, Department of Obstetrics and Gynecology, School of Medicine, University of California, San Francisco, California 94143.

3 We express our appreciation to Mrs. Ya-Yen Yu and Mrs. Frances Wicks for their expert technical assistance.

${ }_{4}^{4}$ Histological staining is used in this paper to encompass all staining procedures other than immunocytochemical techniques.
} 
TABLE 1

Reports on earliest detection of hormones in the human fetal hypophysis or in the medium of pituitary cultures (week of gestation)

\begin{tabular}{|c|c|c|c|c|c|c|c|c|}
\hline \multirow[b]{2}{*}{ Author } & \multirow[b]{2}{*}{ Method } & \multicolumn{7}{|c|}{ Hormone } \\
\hline & & $\begin{array}{c}\text { Growth } \\
\text { hormone }\end{array}$ & $\begin{array}{l}\text { Pro- } \\
\text { Iactin }\end{array}$ & $\begin{array}{l}\text { Cortico- } \\
\text { trophin }\end{array}$ & MSH & LH & FSH & $\begin{array}{l}\text { Thyro- } \\
\text { trophin }\end{array}$ \\
\hline Dubois et al., '73 & IF & & & 7 & & & & \\
\hline Ellis et al., '66 & IF & 12 & & & & & & \\
\hline Fukuchi et al.,'70 & $\underset{\mathrm{BA}}{\mathrm{RIA}}$ & & & & & & & $\begin{array}{l}12 \\
14\end{array}$ \\
\hline Gailani et al., '70 & $\begin{array}{c}\text { TC-RIA } \\
\text { BA }\end{array}$ & 8 & & & & & & \\
\hline Gitlin, Biasucci, '69 & TC-IE & 9 & & & & & 14 & 14 \\
\hline Groom et al., '71 & TC-RIA & & & & & 13 & 13 & \\
\hline Harteman et al., '73 & TC-RIA & $7^{1}$ & & & & $7^{2}$ & & $14+$ \\
\hline Ivanova, Levina, ' 66 & $\mathrm{BA}$ & & & & & & & \\
\hline Kaplan et al., '72 & RIA & 9 & & & & & & \\
\hline Keene, Hewer, '24 & BA & & & & 8 & & & \\
\hline Levina, ' 68 & BA & $15+$ & $18+$ & & 10 & $13+$ & $\begin{array}{l}913+ \\
820+\end{array}$ & $13+$ \\
\hline Levina, Ivanova, '64 & BA & & 19 & & & 18 & & \\
\hline Pavlova et al., ' 68 & PH-BA & 9 & & 9 & & & & \\
\hline
\end{tabular}

thyrotrophs and gonadotrophs in the fetus is inconclusive. Special attention will be given also to the development of zonation in the pars distalis and to cytogenesis in the partes intermedia and tuberalis, as these subjects have received minimal attention to date.

\section{MATERIALS AND METHODS}

Twenty-one human fetuses were obtained by therapeutic and spontaneous abortion (table 2). ${ }^{5}$ Crown-rump (CR) length, crown-heel length and body weight were recorded. Gestational (fertilization) age for this report was determined from the crown-rump length, using the plot of Patten ('68, fig. VII-3). The fetuses ranged from 13 to $217 \mathrm{~mm}$ in CR length, i.e., from 6 to 23 weeks in gestational age. Sex was ascertained in ten cases, but no variations in pituitary cytology could be related to this variable.

The hypophysis and adjoining tissues were excised within 20 minutes after delivery of the fetus and fixed in Bouin's fluid. After dehydration and embedding in paraffin, blocks were sectioned serially at $3 \mu$ with some specimens being cut sagittally and others transversely. Every twentieth section was stained with the Masson ('28) procedure to permit identification of the most propitious areas for immunocytochemical analysis with the peroxidaselabeled antibody method of Nakane and Pierce ('67) or the immunoglobulin-enzyme bridge method of Mason et al. ('69). Almost all of the description of results is based on use of the Nakane-Pierce procedure. The Mason method, because of its greater theoretical sensitivity, was employed when the results were unsatisfactory or maximal sensitivity was desired. Thus the Mason procedure was used on the youngest specimens with antisera to all hormones and in attempting to clarify the incidence of gonadotrophs in all specimens.

Sections adjacent to those stained immunocytochemically were prepared with either the Masson ('28) acid fuchsinponceau de xylidene-aniline blue, DawsonFriedgood ('38) azocarmine-orange G, or Adams and Swettenham ('58) periodic acid-Schiff-Alcian blue-orange $\mathrm{G}$ procedure to permit correlation of immunocytochemical findings with the cell types as revealed by older histological methods.

Antisera ${ }^{6,7}$ to the following hormones were employed for the demonstration of specific cell types as indicated: human

5 The collection of human fetuses used for this study was completed prior to enactment into law of the National Research Act of $\mathbf{1 9 7 4 .}$ 
TABLE 2

Summary of data pertaining to the fetuses studied and to the presence of secretory cell types in the hypophyseal pars distalis

\begin{tabular}{|c|c|c|c|c|c|c|c|c|c|c|}
\hline \multirow{2}{*}{$\begin{array}{l}\text { Speci- } \\
\text { men }\end{array}$} & \multirow[b]{2}{*}{ CRL } & \multirow{2}{*}{$\begin{array}{c}\text { Fertil- } \\
\text { ization } \\
\text { age }\end{array}$} & \multirow[b]{2}{*}{$\begin{array}{c}\text { Menstrual } \\
\text { age }\end{array}$} & \multirow[b]{2}{*}{$\underset{\text { weight }}{\text { Fetal }}$} & \multicolumn{6}{|c|}{ Cell types identified in the pars distalis } \\
\hline & & & & & $\begin{array}{c}\text { Somato- } \\
\text { troph }\end{array}$ & $\underset{\text { troph }}{\text { Mammo- }}$ & $\begin{array}{c}\text { Cortico- } \\
\text { troph }\end{array}$ & $\begin{array}{c}\text { Melano- } \\
\text { troph }\end{array}$ & $\begin{array}{l}\text { Thyro- } \\
\text { troph }\end{array}$ & $\begin{array}{c}\text { Gonado- } \\
\text { troph } \\
\text { (LH) }\end{array}$ \\
\hline & $m m$ & $w k^{2}$ & $w k$ & $g m$ & & & & & & \\
\hline 1 & 13 & 6 & & & 0 & & 0 & 0 & 0 & 0 \\
\hline 2 & $23^{3}$ & $7-$ & & & o & & + & 0 & 0 & 0 \\
\hline 3 & 60 & 10.5 & & 20 & + & & + & 0 & 0 & + \\
\hline 4 & 72 & 11.5 & 12 & 20 & + & 0 & + & 0 & 0 & + \\
\hline 5 & 80 & 12 & 13 & 35 & + & 0 & + & 0 & 0 & + \\
\hline 6 & 90 & 13 & 15 & & + & 0 & + & 0 & + & + \\
\hline 7 & 105 & 14 & 14 & 70 & + & 0 & + & + & + & + \\
\hline 8 & 105 & 14 & & 73 & + & 0 & + & + & + & + \\
\hline 9 & 105 & 14 & 16 & 63 & + & 0 & + & + & 0 & + \\
\hline 10 & 107 & 14 & 14 & 85 & + & 0 & + & + & + & + \\
\hline 11 & 110 & 14 & & 116 & + & 0 & + & + & + & + \\
\hline 12 & 117 & 14.5 & & 118 & + & & + & + & + & + \\
\hline 13 & 125 & 15.5 & 21 & 129 & + & 0 & + & + & + & + \\
\hline 14 & 126 & 15.5 & 18 & 137 & + & 0 & + & + & + & + \\
\hline 15 & 128 & 15.5 & 15 & 116 & + & 0 & + & + & + & + \\
\hline 16 & 131 & 15.5 & & 150 & + & 0 & + & + & + & + \\
\hline 17 & 133 & 16 & 15 & 156 & + & 0 & + & + & + & + \\
\hline 18 & 137 & 16.5 & $14-16$ & 155 & + & 0 & + & + & + & + \\
\hline 19 & 138 & 16.5 & $14-16$ & 153 & + & 0 & + & + & + & + \\
\hline 20 & 144 & 16.5 & 16 & 186 & + & $+?$ & + & + & + & + \\
\hline 21 & 217 & 23 & 28 & 779 & + & + & + & + & + & + \\
\hline
\end{tabular}

1 Crown-rump length.

2 Estimated from the crown-rump length.

3 Crown-tail length.

and bovine growth hormones for the somatotroph; ovine and bovine prolactins for the mammotroph; human thyrotrophin, bovine TSH- $\beta$, and human TSH- $\beta$ for the thyrotroph; human chorionic gonadotrophin and bovine LH- $\beta$ for the LH-gonadotroph; $\beta^{1-24}$ corticotrophin and $\beta^{17-39}$-corticotrophin for the corticotroph; and human $\beta$-melanotrophin for the melanotroph. Specificity of these antisera for delineating cell types has been verified for the rat as follows: antihTSH (Baker and Yu, '71a,b); anti-bTSH- $\beta$ and anti-hCG (Baker et al., '72); and anti- $\beta^{1-24}$-corticotrophin, anti- $\beta_{\mathbf{p}}{ }^{17-39}$-corticotrophin, and anti- $\beta$-MSH (Baker et al., '70; Baker and Drummond, '72). Our present antiserum to human growth hormone shows the same properties for demonstration of somatotrophs in the rat as did the antiserum to a different human growth hormone preparation that was shown previously to be specific (Baker et al., '69). Anti-hCG permits immunocytochemical staining of gonadotrophs in the adult human hypophysis (Baker, '74) and may be used interchangeably with anti-oLH in lower mammals to demonstrate LH-containing cells (Baker et al., '72).

Control procedures were carried out to verify the specificity of these antisera for demonstration of cell types in the human fetus. Thus, when anti-hGH, anti- $\beta^{1-24}$ corticotrophin, anti- $\beta_{\mathrm{p}}{ }^{17-39}$-corticotrophin, and anti- $\beta$-MSH were absorbed with the respective human hormonal antigen prior to use in the immunocytochemical proce-

- Abbreviations will be employed as follows: somatotrophin (growth hormone), GH; thyrotrophin, TSH; luteinizing hormone, LH; melanotrophin (melanocytestimulating hormone), $\mathrm{MSH}$; and human chorionic gonadotrophin, hCG. Antiserum will be designated by the prefix "anti-" before the name of the hormone. A small letter prefix will indicate the species of origin for a hormone, e.g., anti-oLH signifies antiserum to ovine luteinizing hormone.

7 We thank the National Pituitary Agency of the National Institute for Arthritis and Metabolic Diseases for providing human growth hormone (NIH-GH-HS 1395 ), bovine growth hormone (NIH-GH-B5) bovine prolactin (NIH-P-B3) and ovine prolactin (NIH-P-S6). Appreciation is extended also to Professor $\mathrm{H}$. J. Bein and Dr. R. W. Rittel, Ciba-Geigy Ltd., Basle, for $\beta^{1-2 \cdot t_{-}}$ corticotrophin, $\beta_{\mathrm{p}} 17-39$-corticotrophin and human $\beta$ melanotrophin, and to the following individuals for the antisera indicated: Dr. W. D. Odell, anti-hTSH; Dr. J. G. Pierce, Jr., anti-bTSH- $\beta$, anti-hTSH- $\beta$ and anti-bLH-B; and Dr. A. R. Midgley, Jr., anti-hCG and anti-oLH. Antisera to human and bovine growth hormone, bovine and ovine prolactins, $\beta^{1-24}$-corticotrophin,

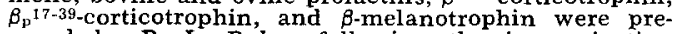
pared by $B$. L. Baker following the immunization schedule of Midgley et al. ('71). 
dure, no staining was obtained. To acquire additional evidence regarding the individuality of the various cell types, immunocytochemical double staining with antisera to two hormones was used, with $3,3^{\prime}$ diaminobenzidine and $\alpha$-naphthol being used as substrates. If two populations of cells of different color were delineated with no cells showing a blend of the two colors, it could be inferred that two distinctly different cell types were present. Verification of the specificity of immunocytochemistry for differentiating thyrotrophs and gonadotrophs proved difficult in the youngest fetuses. This matter will be discussed later.

\section{OBSERVATIONS}

Pituitary cytogenesis and intraglandular distribution of the cell types can be understood more fully if some aspects of the general embryology of the hypophysis are kept in mind. Early in its development, the hypophyseal (Rathke's) pouch is flattened dorsoventrally. At six to seven weeks a midline protuberance termed the "anterior chamber" by Atwell ('26) or the "median diverticulum" by Rouvière et al. ('47) forms on the anterodorsal face. The lateral borders of the flattened hypophyseal pouch proliferate to form marginal cushions, creating a fossa that faces the floor of the brain. The enlarging median diverticulum divides this fossa into bilateral portions and each marginal cushion is divided into medial and lateral parts by an incisure. Ultimately, the median diverticulum and the medial portions of the marginal cushions become the anteromedian zone of the pars distalis while the lateral portions of the marginal cushions become the lateral part of the pars distalis. From the median diverticulum, and probably the marginal cushions (lateral lobes of Atwell, '26), epithelium grows cephalically ventral to the infundibular stem and tuber cinereum to form the pars tuberalis (fig. 15). Mesenchyme fills the fossa (fig. 14) and eventually the bilateral connective tissue trabeculae of the adult gland arise from it (Pietsch, ' 30 ). By proliferation of epithelial tissue, the amount of connective tissue in the fossa becomes reduced relative to the mass of parenchyma (Rouvière et al., '47; Conklin, '68).

\section{Cytogenesis in the pars distalis}

Somatotrophs. Growth hormone cells were absent from the hypophysis at six and seven weeks of gestation (table 2, specimens $S-1,2)$ but were quite numerous at 10.5 weeks (S-3). They are illustrated at 11.5 weeks (figs. 1, 4). It follows that somatotrophs must appear in the pars distalis between 7 and 10.5 weeks. The ovoid to polyhedral somatotrophs were small but stained intensely (fig. 1) with anti-hGH in the immunocytochemical procedure. They occurred in all parts of parēnchymal cell cords and bore no special positional relationship to the capillaries. As early as 10.5 weeks (S-3), and more clearly at 14 weeks (S-8, figs. 5-7), the intraglandular distribution of somatotrophs was generally indicative of the adult pattern. At this time they were most numerous in the lateral wings; in the median zone some somatotrophs were located in the caudal portion near the residual cleft but only a few appeared in the anterior area. Somatotrophs occurred in increasing numbers in all specimens obtained from successively later times in gestation (fig. 8). In the 23-week specimen (S-21) somatotrophs were large and well granulated (fig. 2).

Anti-bovine growth hormone was effective for the immunocytochemical demonstration of some somatotrophs in the human fetus. However, the number seen was much smaller than when antiserum to human growth hormone was used.

Somatotrophs are acidophils and it is important to consider whether their early history could be followed with histological staining. Although somatotrophs were observed immunocytochemically at $\mathbf{1 0 . 5}$ weeks, acidophils were not demonstrable until 11.5 weeks with the Dawson-Friedgood (38) azocarmine-orange $G$ method; with Masson staining they were not observed until 15.5 weeks (S-16; fig. 3). In the eight specimens ranging from 15.5 to 16.5 weeks in gestational age, acidophils were recognized in all but one. In every case they were scarce and usually poorly granulated. On the other hand, in all specimens the immunocytochemical procedure regularly showed that many more cells actually contained growth hormone.

At 23 weeks (S-21) acidophils were quite 
numerous and well granulated. At this time two types were distinguishable. One type contained large, densely packed, bright red cytoplasmic granules and may be the mammotroph. This type occurred in clusters in the median zone. More numerous were acidophils that contained much finer granules of lesser affinity for the red dyes of the Masson combination. Comparison with immunocytochemically stained preparations showed that these cells contained growth hormone.

Mammotrophs (prolactin cells). For demonstration of mammotrophs we were dependent upon antisera to ovine and bovine prolactins, because human prolactin was not available for immunization. With these antisera no specific cells were demonstrable in specimens 1-19. However, a few moderately well stained "mammotrophs" were revealed in S-20 (16.5 weeks) with anti-bovine prolactin, while anti-ovine prolactin was ineffective. At 23 weeks (S-21, fig. 9) more "mammotrophs" appeared in the lateral wings and in the median zone near the residual cleft but they were still much less plentiful than somatotrophs. At this time similar results were obtained with antisera to both ovine and bovine prolactins. Double immunocytochemical staining using anti-hGH and anti-ovine prolactin indicated that somatotrophs (fig. 10) and "mammotrophs" were distinctly different cells. However, a definitive conclusion cannot be drawn because of the small number of "mammotrophs" that could be studied.

Corticotrophs. Corticotrophs were absent from the hypophysis at six weeks (S-1, table 2). However, at seven weeks (S-2) cells appeared along the ventrolateral border of the hypophyseal pouch after immunocytochemical staining with anti$\beta_{\mathrm{p}}{ }^{17-39}$-corticotrophin (fig. 13) but not with $\beta^{1-24}$-corticotrophin. However, the staining was not eliminated by prior absorption of the antiserum with $\beta_{\mathrm{p}}{ }^{17-39}$-corticotrophin. Cytologically these cells differed little from others composing the early anlage of the pars distalis except that they were slightly larger. By 10.5 weeks (S-3) corticotrophs were present in considerable numbers and are illustrated at 11.5 weeks (figs. 12, 14). At 11.5 weeks the large, often ovoid corticotrophs were located pri- marily alongside the vascularized developing trabeculae and their extensions, this relationship existing as far as the incisure (Atwell, '26) where the dorsal mesenchyme enters the hypophyseal fossa (fig. 14). Corticotrophs were also numerous at the lateral and anterolateral borders of the pars distalis. As the gland enlarged with advancing pregnancy, the distribution of corticotrophs along the trabeculae and at the lateral borders of the pars distalis became even more distinctive (S-19, 16.5 weeks; fig. 11). Superiorly in the posteromedian zone corticotrophs formed a bridge across the midline, and in the oldest specimen (S-21, table 2) corticotrophs located in the posteromedian zone were more prominent than those in the lateral wings, where growth hormone cells had become the dominant cell type. Beginning at $\mathbf{1 0 . 5}$ weeks (S-3) anti- $\beta^{1-24}$ and anti- $\beta_{\mathrm{p}}{ }^{17-39}$ corticotrophin proved to be comparably effective for demonstration of corticotrophs.

Comparison of immunocytochemically stained and histologically stained sections showed that corticotrophs are basophils. As early as 10.5 weeks (S-3) the corticotrophs were large, green basophils after application of the Masson procedure. From 10.5 to 14 weeks these cells stained intensely with both immunocytochemical and histological techniques (figs. 18, 19). From 14 weeks on, basophils of many specimens were stained faintly with the Masson procedure, but this feature was not often indicative of light immunocytochemical staining for corticotrophin. Corticotrophs were periodic acid-Schiff (PAS)-positive and in some of the older specimens this reaction was quite intense.

Melanotrophs (MSH-cells). In contrast to the presence of corticotrophs at seven weeks of pregnancy, no immunocytochemical staining with anti-hMSH was obtained until 14 weeks; this hormone was present in hypophyses of all fetuses 14 weeks or older (fig. 20). In most 14-week specimens melanotrophs were quite rare. In one fetus (table 2, S-8; figs. 21-23) with more melanotrophs than the others, their regional distribution was somewhat different from that of corticotrophs in that they were located mainly in the median zone and along capillaries in the lateral areas. The 
parenchyma bordering the trabeculae was almost devoid of MSH staining, as was the most inferior portion of the gland (fig. 23). At 15.5 weeks (S-14; fig. 20) melanotrophs were ovoid, densely granulated, and intensely stained. They were still most numerous in the median zone, especially between the middle and junction with pars tuberalis; also they appeared laterally, particularly along the border of the gland. At later ages, up to and including 23 weeks (S-21), melanotrophs continued to be scarce.

Several procedures were carried out to clarify the relationship of corticotrophs and melanotrophs as demonstrated immunocytochemically. Because the amino acid sequence of hMSH occurs in $\beta^{1-24}$ corticotrophin, immunological cross-reaction between the two hormones might be expected. However, prior absorption of anti- $\beta^{1-24}$-corticotrophin with hMSH or of anti-hMSH with $\beta^{1-24}$ - corticotrophin did not interfere with immunocytochemical staining with either antiserum. These observations suggest that immunological cross-reaction between the two hormones did not result in staining of more than one hormone with each antiserum. Second, sections were doubly-stained immunocytochemically with anti- $\beta^{1-24}$-corticotrophin and anti- $\beta \mathrm{MSH}$. The results, as illustrated by S-21 (table 2 ), were only partially conclusive. Some cells contained only corticotrophin while others contained both corticotrophin and melanotrophin. In these preparations we could not be sure that any cells contained only melanotrophin.

Thyrotroph. With the use of anti-hTSH, presumptive thyrotrophs were first encountered at 13 weeks (S-6; table 2 ) and appeared in all older specimens (fig. 27) except one at 14 weeks. In fetuses 16.5 weeks or younger, thyrotrophs were usually polyhedral and small with little cytoplasm, but the cytoplasm stained intensely. However, by 23 weeks (S-21) the cytoplasmic volume of some cells had increased considerably (fig. 25). Antiserum to the specific subunit of thyrotrophin $(h$ TSH- $\beta$ ) was also useful for delineation of this cell type. Anti-bTSH- $\beta$ was ineffective.

Thyrotrophs constituted a small proportion of the parenchymal cell population.
Although no part of the pars distalis was totally devoid of thyrotrophs, from 13 weeks on they were situated primarly in the anteromedian zone (fig. 24), especially near the midline in the region of junction with the pars tuberalis (fig. 27). Thyrotrophs were exceedingly rare in the pars distalis lateral and inferior to the trabeculae (fig. 24), especially in specimens 15.5 weeks or older.

In the fetus, thyrotrophs did not stain readily with Alcian blue of the AdamsSwettenham ('58) procedure as they do in adult man.

Gonadotrophs (luteinizing-hormone cells). The earliest identification of presumptive gonadotrophs was made at 10.5 weeks (S-3, table 2). They occurred in all older specimens, generally in rather large numbers. From 10.5 through 13 weeks, most gonadotrophs were small, usually stellate, and lightly stained; some were as large as gonadotrophs of the older specimens (fig. 31). Upon first appearing in the pars distalis (S-3) gonadotrophs were common to the anterosuperior region, with very few being found inferior to the level of the trabeculae (fig. 28). With advancing age gonadotrophs became more widely distributed in the pars distalis, being most numerous at the posterolateral borders, between the residual cleft and a plane extending between the trabeculae, and in the anteromedian zone (fig. 29) that continued into the pars tuberalis. They were often especially scarce in the immediate vicinity of the trabeculae and in the anterolateral region of the pars distalis. Double immunocytochemical staining was utilized with the oldest fetus (S-21, table 2) to examine the individuality of gonadotrophs and thyrotrophs. With this procedure they appeared to be distinctly different cell types (fig. 26) although being similar in size and shape.

Anti-bLH- $\beta$ was tried in the immunocytochemical procedure on all hypophyses that gave the strongest staining with anti-hCG. In only the 23-week old fetus (S-21) was it effective. Anti-oLH was used similarly and was ineffective except in two cases (S-11, 20), when some staining was obtained.

In contrast to the ease with which one can demonstrate gonadotrophs in the fe- 
tus with immunocytochemistry, difficulty was experienced with histological staining. With the acid trichrome procedure (Masson, '28), or with Alcian blue-PAS (Adams and Swettenham, '58) (table 2: S-7, 8, 11, $15,19)$ it was usually difficult or impossible to identify any basophils other than those previously shown to be corticotrophs.

\section{Cytogenesis in the pars tuberalis}

$\mathrm{LH}$ was first detected in the pars tuberalis of two fetuses at 15.5 weeks (table 2, S-15, 16; fig. 33) when lightly stained LH-cells ${ }^{8}$ were identified in the anterior portion of the lobe. In the five older fetuses, the pars tuberalis of two contained LHcells. LH-cells appeared throughout the pars tuberalis (fig. 32) of S-19 (16.5 weeks). In the pars tuberalis covering the infundibular stem we did not detect cells that contained growth hormone, corticotrophin (figs. 15, 16), melanotrophin or thyrotrophin (fig. 27), except that a few corticotrophs were located in the inferior portion of the pars tuberalis of two fetuses (S-16, 21).

\section{Cytogenesis in the pars intermedia}

Early in pituitary organogenesis the caudal wall of the hypophyseal pouch could be identified as the pars intermedia. Tubular or follicular arrangements of epithelioid cells grew from the pars intermedia toward the pars nervosa (fig. 27). Similar tubules also partially encased the pars nervosa and surrounded the inferior portion of the infundibular stem (fig. 15).

Rare, lightly stained corticotrophic cells ${ }^{8}$ were found in the pars intermedia of all specimens. The tubules associated with the pars intermedia, whether located between the partes intermedia and nervosa or encompassing the pars nervosa, contained numerous intensely stained corticotrophic cells (fig. 15); this was especially true in the more anterosuperior region (figs. 16, 17). More irregularly from specimen to specimen, staining was obtained also with anti-h $\beta$-MSH, this also being more impressive in the tubules than in the pars intermedia itself (fig. 30). The tubular epithelium of two older specimens (S-16, 19) included a few LH-cells; they were especially prominent in some tubules near the inferior part of the infundibular stem (S-14). In neither the pars intermedia nor its associated tubules was growth hormone, prolactin, or thyrotrophin detected.

\section{DISCUSSION}

It can be concluded from this study that (1) specific secretory cell types appear in the adenohypophysis nearly as soon as the embryonic anlage begins to differentiate, and (2) one of the glycoprotein hormones (gonadotrophin-LH) is synthesized almost as early as the polypeptide hormones.

Somatotrophs. Our results indicate that the production of growth hormone begins between 7 and 10.5 weeks. The large number of intensely stained somatotrophs observed at 10.5 weeks suggests that initiation of hormone synthesis must have occurred considerably earlier. Unfortunately, none of our specimens represented the 7 to 10.5 week period. Most previous investigators (table 1) have found that growth hormone is demonstrable in the human hypophysis at eight to nine weeks. Thus, Gitlin and Biasucci ('69) observed that pituitary glands from fetuses at eight and one-half weeks could synthesize growth hormone when grown in culture, but those from younger specimens could not.

It seems likely that technical problems may have accounted for the failure of Ellis et al. ('66) to detect somatotrophs consistently by immunofluorescence before 17 weeks. Even at 14 to 16 weeks they found somatotrophs to be infrequent, which differs markedly from our observations. Similarly, insensitivity of the bioassay procedure may explain why Levina ('68) detected no growth hormone in the gland before 15 weeks.

Our successful demonstration of some somatotrophs in the fetal hypophysis with antiserum to bovine growth hormone was unexpected. Previously Nayak et al. ('69) reported that somatotrophs could not be detected in hypophyses of human adults when anti-bGH was used with immunofluorescence. Furthermore, they observed no cross-reaction between antiserum to bo-

\footnotetext{
Cells in the partes tuberalis and intermedia that contain a hormone are designated by the name of the hormone only because the functional role of these cells has not been demonstrated conclusively. Examples: LH-cells, corticotrophic cells, MSH-cells.
} 
vine growth hormone and human growth hormone in a hemagglutination test. This conflict in experimental observations could result from a difference in the antigenic properties of growth hormone in the fetal hypophysis as compared with the adult. Thus, there may be incomplete "maturation" of the hormone in the fetus or it may respond differently to the fixing fluid.

Some disagreement exists concerning the time when acidophils appear in the hypophysis and whether synthesis of growth hormone precedes the formation of storage granules that enable the cytologist to recognize acidophils. In our series, intracellular growth hormone was demonstrable before acidophils could be identified. Although immunocytochemistry revealed abundant somatotrophs at 10.5 weeks, acidophils as stained with orange $\mathrm{G}$ of the Dawson-Friedgood procedure were first observed in small numbers at 11.5 weeks. Application of either the Dawson-Friedgood or Masson technique resulted in irregular demonstration of acidophils until 14.5 weeks after which time they appeared in variable numbers in all specimens. However, in all specimens younger than 23 weeks, immunocytochemistry revealed far more somatotrophs than did histological staining.

Many investigators have reported acidophils to be present much earlier: Daikoku ('58) at eight weeks (30-mm CR length), Falin ('61) at nine weeks, Pearse ('53) and Conklin ('68) at 11 weeks, Ellis et al. ('66) at 12 to 16 weeks, and Romeis ('40) at 13 weeks. The discrepancies in these observations probably result from variations in technical procedures and in criteria for identification of an acidophil. In contrast to several fixatives used by others which preserve mitochondria well, e.g., Zenkerformol or formalin, the acetic acid of Bouin's fluid used in our study makes mitochondria unstainable and thus eliminates confusion of these organelles with cytoplasmic granules. Thus we may have been able to make a more certain identification of acidophils than some other investigators.

A great increase in number and size of acidophils occurs by 16 to 21 weeks (Pearse, '53; Levina, '68; Levina and Ivanova, '64); in our series this development was especially significant at 23 weeks
(S-21). Not only are the somatotrophic acidophils the dominant cell type during the last half of pregnancy, but the pituitary content. of growth hormone also increases with advancing gestation (Kaplan et al., '72; Gitlin and Biasucci, '69; Pavlova et al., '68).

Mammotroph. Although histological staining revealed the presence of two types of acidophils at 23 weeks, our designation of one of them as a "mammotroph" cannot be considered conclusive for reasons previously stated. Indeed, Goluboff and Ezrin ('69) did not observe prolactin cells in the hypophyses of three fetuses 31 to 38 weeks old after staining with the Brookes carmoisine S-orange $G$ method. Nevertheless, in agreement with our observation is the finding of Levina ('68) that prolactin is first detectable in the fetal hypophysis at about 19 weeks.

Corticotroph/melanotroph. Dubois et al. ('73) recently reported the presence of corticotrophs in the median "posterior lamina" of the hypophysis of a 7-week human fetus as demonstrated by means of immunofluorescence. Anti- $\beta_{\mathrm{p}}{ }^{17-39}$-corticotrophin, but not anti- $\beta^{1-24}$-corticotrophin, was effective. With our one 7 -week specimen (S-2), we also observed staining with anti- $\beta_{p}{ }^{17-39}$-corticotrophin only, but it could not be prevented by prior absorption of the antiserum with $\beta_{\mathbf{p}}{ }^{17-39}$-corticotrophin. Thus, some question exists concerning the presence of corticotrophin at this time. The adequacy of anti- $\beta_{\mathrm{p}}{ }^{17-39}$-corticotrophin for immunocytochemical demonstration of corticotrophin in man is supported by the discovery that the amino acid sequence of porcine corticotrophin is identical to that of man except for substitution of serine for leucine at the 31 position (Riniker et al., '72). We do concur with the conclusion of Dubois et al. that subsequently during human gestation anti- $\beta_{\mathrm{p}}{ }^{17-39}$-corticotrophin and anti- $\beta^{1-24}$-corticotrophin are equally effective for the immunological study of corticotrophs. The demonstration with bioassay of corticotrophic activity in the hypophysis of 9-week old fetus by Pavlova et al. ('68) also supports the contention that elaboration of this hormone begins early. Evidence presently available indicates that corticotrophin is the first hor- 
mone to be synthesized by the pars distalis in man.

We have shown that corticotrophs are basophils. These basophils are demonstrated easily by histological staining and can be identified between the eighth and eleventh weeks along the borders of the vascularized mesenchyme that invades the pituitary fossa (Pearse, '53; Daikoku, '58; Falin, '61; Pavlova et al., '68). They are the $\beta$-cells of Romeis ('40) and Type I basophils of Andersen et al. ('70) which were observed at eight weeks ( 28 to $30 \mathrm{~mm}$ CR length) by these investigators. Conklin ('68) reported such basophils to be present at seven weeks and, like Pavlova et al. ('68), correctly ascribed to them the secretion of corticotrophin.

The conclusion that corticotrophin appears between the seventh and tenth weeks is supported strongly by the secretory status of the adrenal cortex. In an 8.5 week fetus Murphy and Diez d'Aux ('72) found no cortisol, but total adrenal corticoids were exceedingly high, as was cortisol, at 11 weeks. They concluded that the adrenal cortex functions from the first trimester on. Our study shows that the hypophysis is competent to stimulate the adrenal cortex at this time.

Because the $\beta$ basophil of the adult hypophysis contains both corticotrophin and melanotrophin (Phifer et al., '70; Baker, '74), it is of particular interest to know whether the same situation exists in fetal life. Dubois et al. ('73) concluded that it does. With double immunocytochemical staining we have shown that some corticotrophs contain melanotrophin while others do not. Different cells of origin might be indicated by the fact that the hypophysis initiates its production of the two hormones at somewhat different times. Although the evidence indicates that corticotrophin may appear as early as seven weeks, we did not detect melanotrophin until 14 weeks; it was present in all of our specimens older than 14 weeks. Dubois et al. ('73) agree that melanotrophin arises later than corticotrophin. Also suggestive of different cells of origin was a disparity in regional distribution of corticotrophs and melanotrophs. In contrast to corticotrophs, the cells containing melanotrophin were fewer in number and fre- quently did not exhibit a distinctive regional distribution in the gland. However, in some specimens melanotrophs occurred in the anteromedian zone, a location not frequented by corticotrophs. This observation suggests that some cells may contain melanotrophin in the absence of corticotrophin, even though this was not demonstrated with double immunocytochemical staining.

Thyrotrophs. When anti-hTSH was used with the immunocytochemical procedure, thyrotrophs were observed first at 13 weeks and in all older specimens except one. This finding agrees closely with the observations of all previous investigators who have sought thyrotrophin in the hypophysis (table 1); they reported its presence at 12 to 14 weeks. However, the status of the fetal thyroid suggests that pituitary control may be effective somewhat earlier. Thus at 10 to 11 weeks, the ratio of thyroid weight to body weight reaches the adult level (Shepard et al., '64), follicles begin to accumulate colloid (Norris, '16), and the capacity to iodinate organic substance begins (Shepard, '67). Thyrotrophin and thyroxine are detectable in fetal umbilical cord blood as early as 12 weeks (Fisher et al., '70).

Undoubtedly previous investigators have successfully differentiated thyrotrophs in the human fetus by means of histological staining. The Type II alcianophilic basophil which Andersen et al. ('70) observed first in 11 to 12 week embryos may be the thyrotroph. Conklin ('68) also concluded that thyrotrophs (Alcian blue-positive) arise at 12 weeks but he viewed them as being characteristic of the lateral wings rather than the median zone. In our study they constituted only a small percentage of the parenchymal cell population; they were located primarily in the median zone, especially in its superior portion. Few thyrotrophs could be found in the lateral wings. Prior to 23 weeks thyrotrophs were small with little cytoplasm and possessed long thin processes. At 23 weeks they were larger and contained denser cytoplasm than was true of the younger fetuses.

Gonadotrophs. The status of knowledge regarding gonadotrophs in the fetal hypophysis, and their secretory activity, has been unsatisfactory. In view of the ease 
with which gonadotrophs can be demonstrated immunocytochemically in the fetal hypophysis, the previous difficulty experienced by cytologists in delineating them is of special interest. With histological methods, few investigators of the human fetal hypophysis have attempted to subdivide the basophils into categories that might produce corticotrophin (melanotrophin), thyrotrophin, or gonadotrophic hormones. When such attempts have been made there was minimal justification for attributing functions to the various cell types. As reviewed previously, corticotrophic basophils, because of their prominence, have been noted by most workers. Few workers have indicated a source for gonadotrophin. Romeis ('40) first found $\gamma$-cells at the nineteenth to twentieth week $(180 \mathrm{~mm}$ CRL) and 8-cells at the forty-second week (230 $\mathrm{mm}$ CRL). Similarly the basophils that Conklin (68) considered to be the source of LH and FSH were observed first at 22 and 23 weeks, respectively.

The weight of the evidence shows that gonadotrophins are present in the hypophysis much earlier than this. In addition to our observations with immunocytochemistry, it is generally recognized that both FSH and LH are demonstrable in the fetal hypophysis at 13 weeks and subsequently (table 1). Using a hemagglutination test for LH and bioassay for $\mathrm{FSH}$, Levina ('72) reported the presence of LH activity in serum beginning at the 18th week with a peak occurring at 20 to 26 weeks; the level of FSH followed a similar pattern. Subsequently there was a sharp fall, with the concentration of both hormones being exceedingly low during weeks 27 to 32 .

Specificity of the immunocytochemical methods for differentiation of thyrotrophs and gonadotrophs warrants further consideration. In specimens older than $\mathbf{1 5 . 5}$ weeks the achivement of specificity was indicated by the following observations. First, double immunocytochemical staining revealed that different cells contained thyrotrophin and gonadotrophin. Second, the antiserum to human thyrotrophin, which contained antibodies to $\mathrm{LH}$, was absorbed with hCG before use. This treatment eliminates immunocytochemical labeling of gonadotrophs in adult rat and man. Third, the loss in effectiveness of anti-hCG after absorption with human thyrotrophin was probably due to contamination with $\mathrm{LH}$, a condition widely recognized to occur in such preparations. This outcome does not necessarily indicate that anti-hCG is ineffective for differentiating gonadotrophs from thyrotrophs, although the possibility of direct cross-reaction must be considered since Nisula et al. ('74) believe that human chorionic gonadotrophin possesses intrinsic thyrotrophic activity. Fourth, the regional distributions of gonadotrophs (fig. 29) and thyrotrophs (fig. 24) are vastly different.

In some of the younger specimens (1315.5 weeks ) differentiation of the two cell types was less conclusive. At least in median sagittal sections the distributions of cells containing thyrotrophin (fig. 27) and gonadotrophin (fig. 28) were similar. Because human TSH, FSH and LH possess a common a-subunit(Nisula et al., '73; Vaitukaitis et al., '73), possible immunologic cross-reaction between these hormones must be considered. On the other hand, it is conceivable that during early genesis of thyrotrophs and gonadotrophs, two or more of the glycoprotein hormones might occur in a single cell. Investigation of this difficult problem continues.

In conclusion, the times when specific secretory cell types appear in the pars distalis of the human fetal hypophysis agree rather well with evidence regarding the first occurrence of the various hormones within the blood.

It may be significant that LH-containing cells represent the only cell type identifiable in the pars tuberalis. They occur in the pars tuberalis of the human adult as shown by immunofluorescence (Midgley, '66). Similarly, only LH-cells were found with immunocytochemistry in the pars tuberalis of adult rats (Baker, unpublished) although electron microscopy indicates that more than one secretory type may be present (Klein et al., '70).

\section{LITERATURE CITED}

Adams, C. W. M., and K. V. Swettenham 1958 The histochemical identification of two types of basophil cell in the normal human adenohypophysis. J. Path. Bact., 75: 95-103.

Andersen, H., K. Mollgärd and F. A. Von Bülow 1970 On the specificity of staining by Alcian 
blue in the study of human foetal adenohypophysis. Histochemie, 22: 362-375.

Atwell, W. J. 1926 The development of the hypophysis cerebri in man, with special reference to the pars tuberalis. Am. J. Anat., 37. 159-193.

Baker, B. L. 1974 Functional cytology of the hypophysial pars distalis and pars intermedia. In: The Pituitary Gland and Its Control Adenohypophysis. Handbook of Physiology, Endocrinology IV, Part 1. Am. Physiol. Soc. Bethesda, pp. 45-80.

Baker, B. L., and T. Drummond 1972 The cellular origins of corticotropin and melanotropin as revealed by immunochemical staining. Anat. Rec., 134: 395-409.

Baker, B. L., A. R. Midgley, Jr., B. E. Gersten and Y.-Y. Yu 1969 Differentiation of growth hormone- and prolactin-containing acidophils with peroxidase-labeled antibody. Anat. Rec., 164: 163-171.

Baker, B. L., S. Pek, A. R. Midgley, Jr. and B. E. Gersten 1970 Identification of the corticotropin cell in rat hypophyses with peroxidaselabeled antibody. Anat. Rec., 166: 557-567.

Baker, B. L., J. G. Pierce and J. S. Cornell 1972 The utility of antiserums to subunits of TSH and LH for immunochemical staining of the rat hypophysis. Am. J. Anat., 135: 251-267.

Baker, B. L., and Y.-Y. Yu 1971a The thyrotropic cell of the rat hypophysis as studied with peroxidase-labeled antibody. Am. J. Anat, 131: $55-71$.

1971b Hypophyseal changes induced by thyroid deficiency and thyroxine administration as revealed by immunochemical staining. Endocrinology, 89: 996-1004.

Brookes, L. D. 1968 A stain for differentiating two types of acidophil cells in the rat pituitary. Stain Techn., 43: 41-42.

Conklin, J. L. 1968 The development of the human fetal adenohypophysis. Anat. Rec., 160: 79-91.

Daikoku, S. 1958 Studies on the human foetal pituitary. 2. On the form and histological development, especially that of the anterior pituitary. Tokushima J. Exp. Med., 5: 214-231.

Dawson, A. B, and H. B. Friedgood 1938 Differentiation of two classes of acidophiles in the anterior pituitary of the female rabbit and cat. Stain Tech., 13: 17-21.

Dubois, P., H. Vargues-Regairaz and M. P. Dubois 1973 Human foetal anterior pituitary immunofluorescent evidence for corticotropin and melanotropin activities. $\mathrm{Z}$ : Zellforsch., 145: 131-143.

Ellis, S. T., J. S. Beck and A. R. Currie 1966 The cellular localisation of growth hormone in the human foetal adenohypophysis. J. Path. Bact., 92: 179-183.

Falin, L. I. 1961 The development of human hypophysis and differentiation of cells of its anterior lobe during embryonic life. Acta Anat., 44: 188-205.

Fisher, D. A., C. J. Hobel, R. Garza and C. A. Pierce 1970 Thyroid function in the preterm fetus. Pediatrics, 46: 208-216.
Fukuchi, M., T. Inoue, H. Abe and Y. Kumahara 1970 Thyrotropin in human fetal pituitaries. J. Clin. Endocr. Metab., 31: 565-569.

Gailani, S. D., A. Nussbaum, W. J. McDougall and W. F. McLimans 1970 Studies on hormone production by human fetal pituitary cell cultures. Proc. Soc. Exp. Biol. Med., 134: 27-32.

Gitlin, D., and A. Biasucci 1969 Ontogenesis of immunoreactive growth hormone, folliclestimulating hormone, thyroid-stimulating hormone, luteinizing hormone, chorionic prolactin and chorionic gonadotropin in the human conceptus. J. Clin. Endocr., 29: 926-935.

Goluboff, L. G., and C. Ezrin 1969 Effect of pregnancy on the somatotroph and the prolactin cell of the human adenohypophysis. J. Clin. Endocr., 29: 1533-1538.

Groom, G. V., M. A. Groom, I. D. Cooke and A. R. Boyns 1971 The secretion of immunoreactive luteinizing hormone and follicle-stimulating hormone by the human foetal pituitary in organ culture. J. Endocr., 49: 335-344.

Hartemann, Ph., D. Malaprade, D. Lemoine, G. Grignon, P. Nabet and M. Pierson 1973 Mise en évidence des éléments morphologiques et des activités sécrétoires STH et LH dans l'hypophyse de foetus humain au cours du développement. C. R. Soc. Biol., 167: 105-110.

Ivanova, E. A., and S. E. Levina 1966 Biological estimation of thyrotrophin in the pituitary of the human embryo and the placenta. Dokl. Akad. Nauk., SSSR, 167: 1423-1426.

Kaplan, S. L., M. M. Grumbach and T. H. Shepard 1972 The ontogenesis of human fetal hormones. I. Growth hormone and insulin. J. Clin. Invest, 51: 3080-3093.

Keene, M. F. L., and E. E. Hewer 1924 Glandular activity in the human foetus. Lancet, 2: 111-112.

Klein, M.-J., M.-E. Stoeckel, A. Porte and F. Stutinsky 1970 Arguments ultrastructuraux en faveur de l'existence de cellules corticotropes (à ACTH) dans la pars intermedia et dans la pars tuberalis de l'hypophyse du rat. C. R. Acad. Sci. (Paris), Ser. D, 271: 2159-2162.

Levina, S. E. 1968 Endocrine features in development of human hypothalamus, hypophysis, and placenta. Gen. Comp. Endocr., 11: 151-159.

972 Times of appearance of LH and FSH activities in human fetal circulation. Gen. Comp. Endocr., 19: 242-246.

Levina, S. E., and E. A. Ivanova 1964 Biological determination on pituitary prolactin in the human embryo. Dokl. Akad. Nauk, SSSR, 155: 988-991.

Mason, T. E., R. F. Phifer, S. S. Spicer, R. A. Swallow and R. B. Dreskin 1969 An immunoglobulin-enzyme bridge method for localizing tissue antigens. J. Histochem. Cytochem., 17: $563-569$.

Masson, P. 1928 Carcinoids (argentaffin-cell tumors ) and nerve hyperplasia of the appendicular mucosa. Am. J. Path., 4: 181-212. 
Midgley, A. R., Jr. 1966 Human pituitary luteinizing hormone: an immunohistochemical study. J. Histochem. Cytochem., 14: 159-166.

Midgley, A. R., Jr., G. D. Niswender, V. L. Gay and L. E. Reichert, Jr. 1971 Use of antibodies for characterization of gonadotropins and steroids. Rec. Progr. Horm. Res., 27: 235-301.

Murphy, B. E. P., and R. C. Diez d'Aux 1972 Steroid levels in the human fetus: cortisol and cortisone. J. Clin. Endocr. Metab., 35: 678-683.

Nakane, P. K., and G. B. Pierce, Jr. 1967 Enzyme-labeled antibodies for the light and electron microscopic localization of tissue antigens. J. Cell Biol., 33: 307-318.

Nayak, R., E. E. McGarry and J. C. Beck 1969 Studies with fluorescein-conjugated antisera to growth hormones. I. Localization of antisera in the pituitary in various species. Canad. J. Physiol. Pharmacol, 47: 15-19.

Nisula, B. C., P. O. Kohler, J. L. Vaitukaitis, J. M. Hershman, and G. T. Rose 1973 Neutralization of human thyrotropin by antisera to subunits of glycoprotein hormones. J. Clin. Endocr. Metab., 37: 664-669.

Nisula, B. C., F. J. Morgan and R. E. Canfield 1974 Evidence that chorionic gonadotropin has intrinsic thyrotropic activity. Biochem. Biophys. Res. Commun., 59: 86-91.

Norris, E. H. 1916 The morphogenesis of the follicles in the human thyroid gland. Am. J. Anat., 20: 411-448.

Patten, B. M. 1968 Human Embryology. Third ed. The Blakiston Division, McGraw-Hill Book Company, New York.

Pavlova, E. B., T. S. Pronina and Y. B. Skebelskaya 1968 Histostructure of adenohypophysis of human fetuses and contents of somatotropic and adrenocorticotropic hormones. Gen. Comp. Endocr., 10: 269-276.
Pearse, A. G. E. 1953 Cytological and cytochemical investigations on the foetal and adult hypophysis in various physiological and pathological states. J. Path. Bact., 65: 355-370.

Phifer, R. F., S. S. S. Spicer and D. N. Orth 1970 Specific demonstration of the human hypophyseal cells which produce adrenocorticotropic hormone. J. Clin. Endocr. Metab., 31: 347-361.

Pietsch, K. 1930 Aufbau and Entwicklung der Pars tuberalis des menschlichen Hirnanhangs in ihren Beziehungen zu den übrigen Hypophysenteilen. Z. mikro. Anat. Forsch., 22: 227258.

Riniker, B., P.Sieber, W. Rittel and H. Zuber 1972 Revised amino-acid sequences for porcine and human adrenocorticotrophic hormone. Nature New Biol., 235: 114-115.

Romeis, B. 1940 Innersekretorische Drüsen. II. Hypophyse. Handb. mikro. Anat. Menschen. Vol. 6. Part 3. W. von Möllendorff, ed. Julius Springer, Berlin.

Rouvière, H., A. Giraud, P. Desclaux and P. Roux 1947 Le développement du lobe antérieur de l'hypophyse et ses conséquences physio-pathologiques. Ann. Anat. Path., 17: 113-124.

Shepard, T. H. 1967 Onset of function in the human fetal thyroid: biochemical and radioautographic studies from organ culture. J. Clin. Endocr., 27: 945-958.

Shepard, T. H., N. J. Andersen and H. Andersen 1964 The human fetal thyroid. I. Its weight in relation to body weight, crown-rump length, foot length and estimated gestation age. Anat. Rec., 148: 123-128.

Vaitukaitis, J. L., G. T. Ross, J. G. Pierce, J. S. Cornell and L. E. Reichert, Jr. 1973 Generation of specific antisera with the hormonespecific $\beta$-subunit of hTSH or hFSH. J. Clin. Endocr. Metab., 37: 653-659. 


\section{PLATES}


All preparations illustrated were stained with the Nakane-Pierce ('67) conjugated antibody procedure except those for figures $13 a, b, 28$ and 30 , which were prepared with the immunoglobulin-enzyme bridge technique of Mason et al. ('69).

Abbreviations

$\begin{array}{ll}\text { C, residual cleft } & \text { N, pars nervosa } \\ \text { D, pars distalis } & \text { P, hypophyseal pouch } \\ \text { I, infundibulum } & \text { PI, pars intermedia } \\ \text { IP, infundibular process } & \text { s, somatotroph } \\ \text { M, median zone } & \text { T, pars tuberalis } \\ \text { m, mammotroph } & \text { tr, trabecula } \\ \text { ME, median eminence } & \text { tu, tubule }\end{array}$

PLATE 1

EXPLANATION OF FIGURES

In all illustrations immunocytochemical staining was used unless stated to the contrary.

1. Somatotrophs in the pars distalis of S-4 (table 2) (11.5 weeks). This is an enlargement of an area shown in figure 4 . The cells are small, polyhedral and in most instances have few cytoplasmic granules. Anti-hGH. $\times 1000$.

2 Somatotrophs in the pars distalis of S-21 (23 weeks). As compared with those at 11.5 weeks (fig. 1) somatotrophs are larger and more ovoid. Anti-hGH. $\times 1000$.

3 Acidophils (arrows) in the pars distalis of S-14 (15.5 weeks). This is the youngest specimen in which acidophils could be identified after staining with the Masson procedure. $\times 1000$.

4 Somatotrophs (dark cells) in the region of the pars distalis lateral to one of the paired trabeculae in S-4 (11.5 weeks). Sagittal section, immunocytochemical staining with anti-hGH. $\times 100$.

5, 6, 7 Transverse sections through the hypophysis of S-8 (14 weeks) to show the distribution of somatotrophs. Figure 5 is superior and includes portions of the pars nervosa, junction of the pars nervosa with the infundibular stem, pars intermedia, residual cleft and one wing of the pars distalis. Somatotrophs are distributed laterally and posteriorly in the pars distalis, and are absent from the zone of junction with the pars tuberalis. In figure 6 the residual cleft, pars intermedia with its accompanying tubules, and one trabecula (tr) in the lateral zone of the pars distalis are shown. Somatotrophs are most numerous posteriorly and laterally, except in the immediate vicinity of the trabecula. They are scarce in the anteromedian (M) zone. The section shown in figure 7 is inferior to that for figure 6. Most somatotrophs are located posteriorly and few are present anteriorly. Immunocytochemical staining with anti-hGH. $\times 42$. 

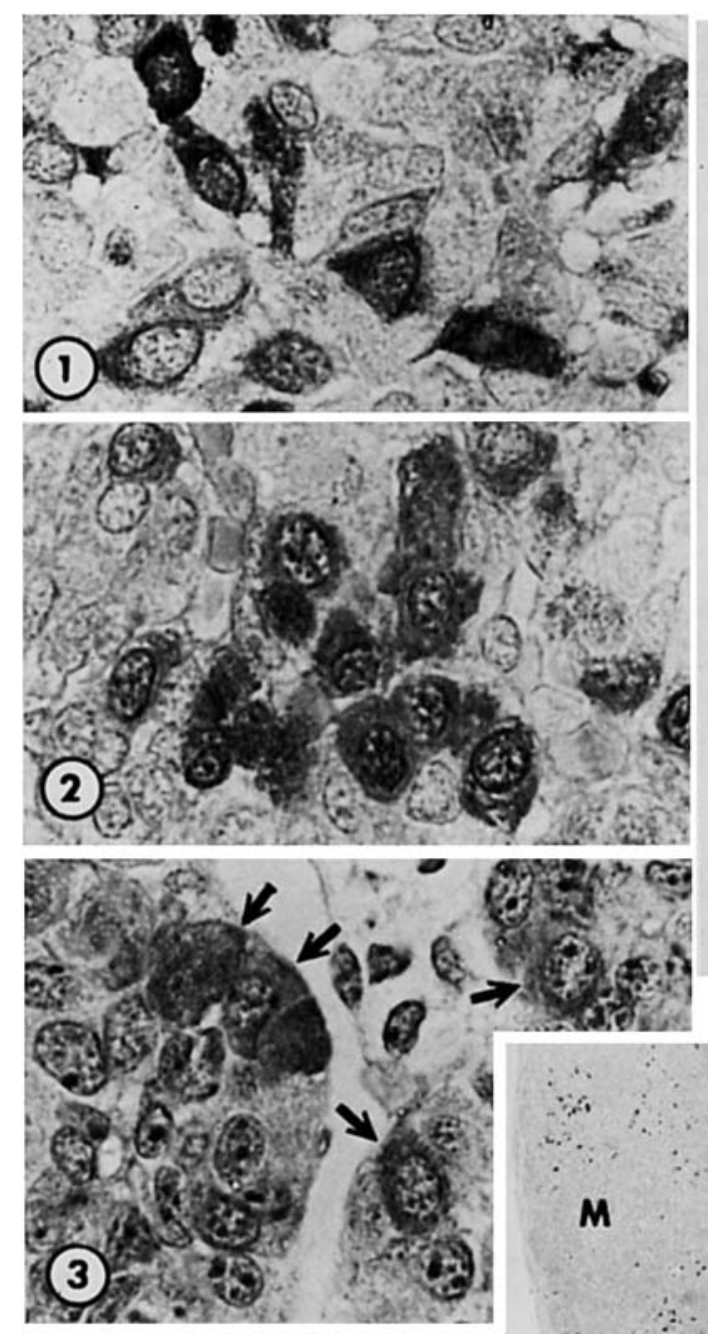

B) 6) 20.2 ?

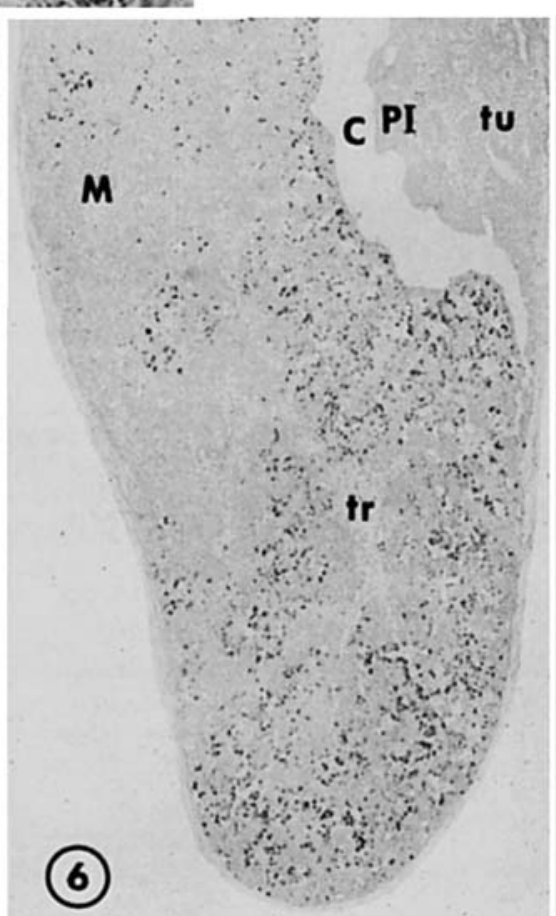

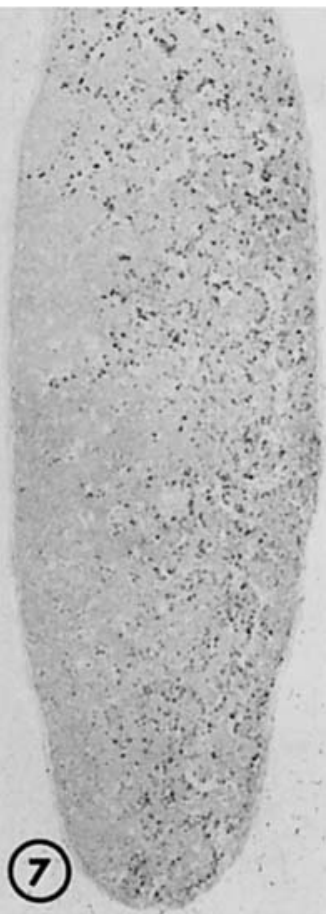




\section{PLATE 2}

EXPLANATION OF FIGURES

All sections were prepared with immunocytochemistry.

8 Transverse section through the hypophysis of S-21 (23 weeks) showing the distribution of somatotrophs. They are most numerous in the posterior portion of the median zone (M) and laterally except in the immediate vicinity of the trabecula (tr). They are absent from the anterior portion of the median zone and from the pars intermedia (PI) with its tubules. Anti-hGH. $\times 34$.

9 A "mammotroph" ( $m$ ) from the pars distalis of S-21 (23 weeks). Anti-o prolactin. $\times 1000$.

10 Differentiation of somatotrophs (arrows) from a mammotroph ( $m$ ) by double-immunocytochemical staining. Anti-hGH with diaminobenzidine as substrate was used for the somatotroph and anti-o prolactin with a-naphthol-pyronin for the mammotroph. $\times 1000$.

11 Transverse section through the hypophysis of $\mathrm{S}-19$ (16.5 weeks) to show the distribution of corticotrophs. They are most frequent adjacent to the trabecula (tr) and its extensions, as well as along the anterolateral border of the pars distalis. Some staining is evident in the pars intermedia (PI). Almost no corticotrophs appear in the anterior part of the median zone. Anti- $\beta^{1-24}$-corticotrophin. $\times 42$.

12 Corticotrophs border a trabecula in the pars distalis of S-4 (11.5 weeks). They vary in size and may be ovoid or polyhedral. Anti$\beta_{p}{ }^{17-39}$-corticotrophin. $\times 1000$. 

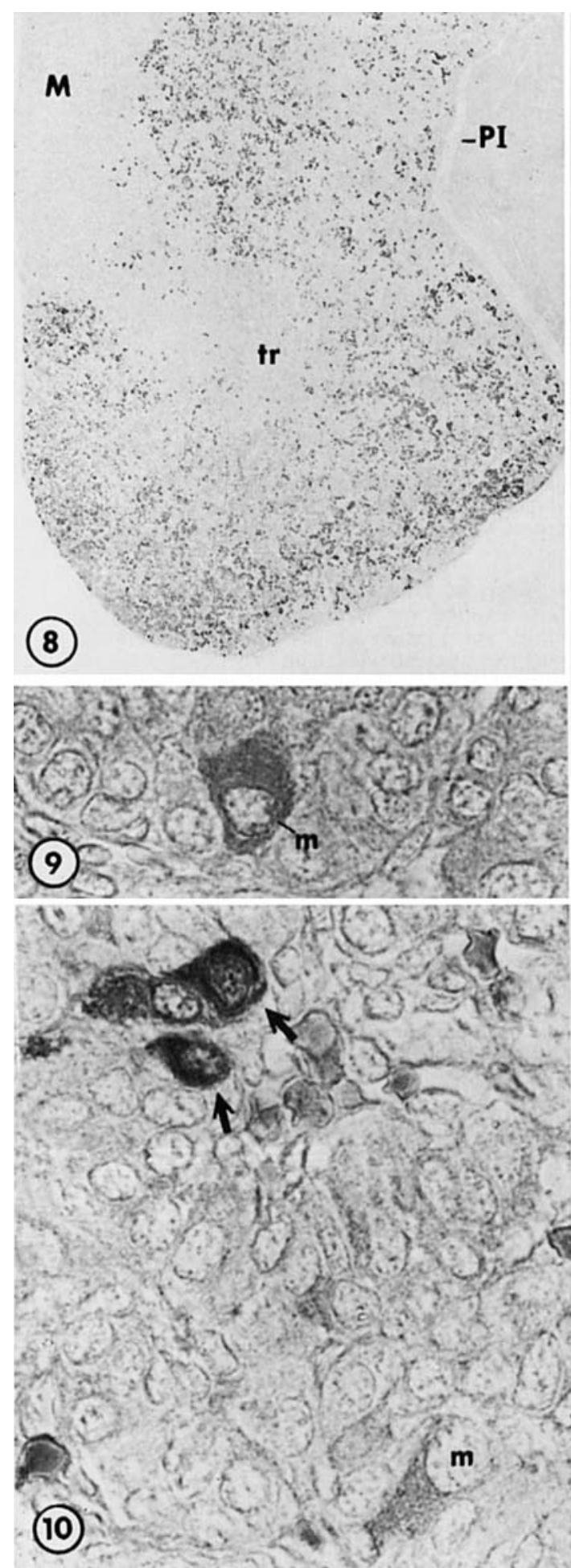

M
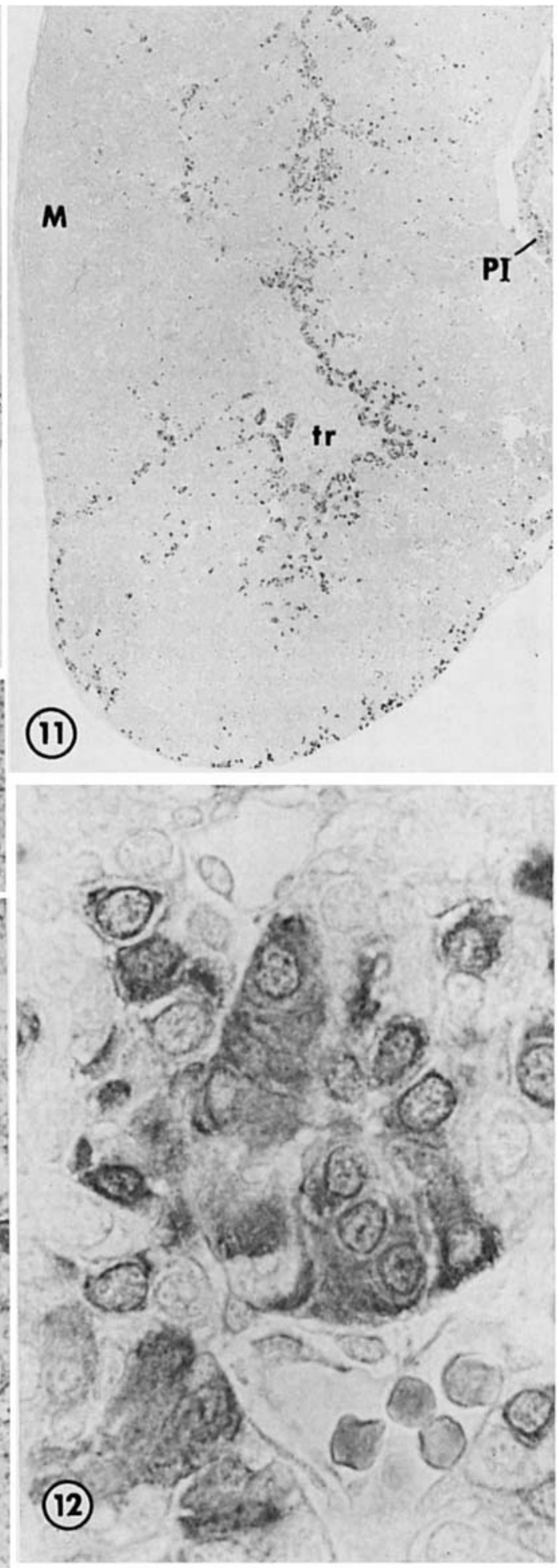
PLATE 3

EXPLANATION OF FIGURES

All sections were prepared with immunocytochemistry.

13 a. Sagittal section through the lateral portion of the hypophyseal pouch of S-2 (7 weeks) stained with the Mason et al. ('69) technique utilizing anti- $\beta_{p}{ }^{17-39}$-corticotrophin. Staining has occurred along the ventro-caudal border of the pouch (arrows). $\times 100$. b. The area of staining indicated in figure 13a is illustrated at higher magnification. The cells containing corticotrophin show little structural modification from those constituting the remainder of the pouch. $\times 325$.

14 A lateral sagittal section through the hypophysis of S-4 (11.5 weeks) showing the distribution of corticotrophs. Mesenchyme has invaded the pars distalis at the incisure (X) to form a trabecula ( $\mathrm{tr}$ ). Corticotrophs are located chiefly along the invading mesenchyme and near the inferior border of the pars distalis. Some corticotrophic cells are associated with the pars intermedia (PI) $\times 52$.

15 Sagittal section of S-14 (15.5 weeks) illustrating all subdivisions of the hypophysis. Corticotrophs occur along vascular connective tissue of the pars distalis and at the inferior border of this lobe. A few positive cells appear in the pars intermedia (PI) and more in the tubules ( $\mathrm{tu}$ ) adjacent to the pars nervosa and superior to the infundibulum. No corticotrophs are found in the pars tuberalis ( $T$ ) and few in the anteromedian zone of the pars distalis. Anti- $\beta^{1-24}$-corticotrophin. $\times 42$.

16 Corticotrophin-containing cells in an oblique frontal section through the median eminence (ME), infundibular stem, and superior part of the pars distalis of S-19 (16.5 weeks). Corticotrophs are scattered in the pars distalis and corticotrophic cells are abundant in the tubules (tu) derived from the pars intermedia. None occur through the full extent of the pars tuberalis ( $T$ ) or the zone of junction between it and the pars distalis. Anti- $\beta_{\mathbf{1}}{ }^{17-39}$-corticotrophin. $\times 42$.

17 An enlargement of the area indicated by the rectangle in figure 10. Many corticotrophic cells occur in the pars intermedia (PI) and the associated tubules (tu). $\times 400$. 

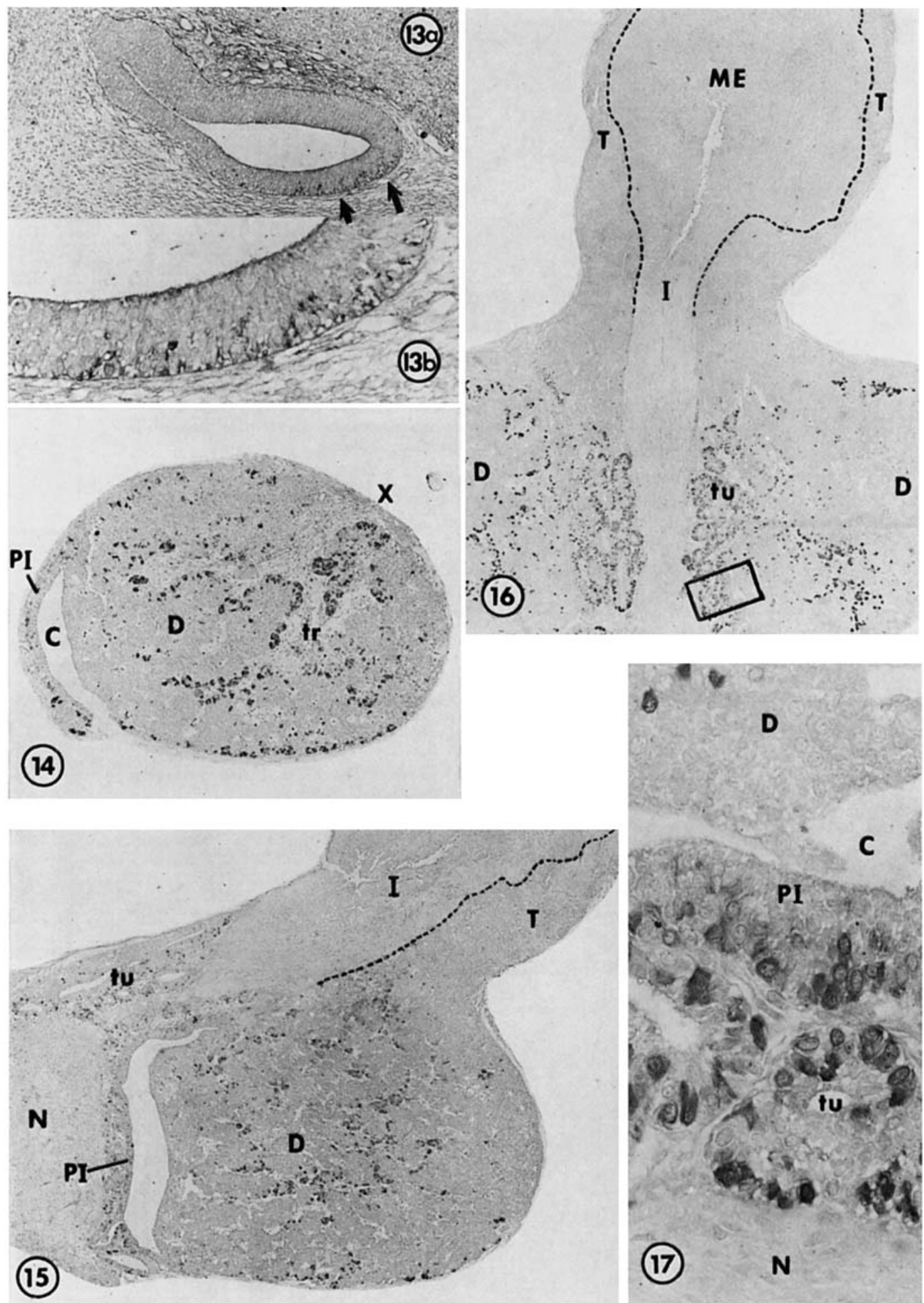


\section{PLATE 4}

EXPLANATION OF FIGURES

18 Peripheral border of the pars distalis of S-4 (11.5 weeks) stained with the Masson procedure to show the basophils (arrows) that are corticotrophs. $\times 600$.

19 Portion of the pars distalis of S-8 (14 weeks) bordering a trabecula ( $t r$ ) and stained with the Masson procedure to show corticotrophic basophils (arrows). $\times 600$.

20 Melanotrophs in the pars distalis of S-14 (15.5 weeks) Like the corticotrophs, melanotrophs (arrows) frequent the borders of vascularized connective tissue strands. Immunocytochemical staining with anti-h $\beta$-MSH. $\times 1000$.

$21,22,23$ As figures 5-7, these are transverse sections through the hypophysis of S-8 (14 weeks). They are stained to show the distribution of melanotrophs. In the superior section (fig. 21) they are few in the pars distalis but more numerous in tubules associated with the pars intermedia. In a deeper section (fig. 22) melanotrophs populate the median zone (M) and some occur laterally (arrow); in this case the peritrabecular region (tr) is almost devoid of melanotrophs. The inferior section (fig. 23) has very few melanotrophs. $\times 42$. 

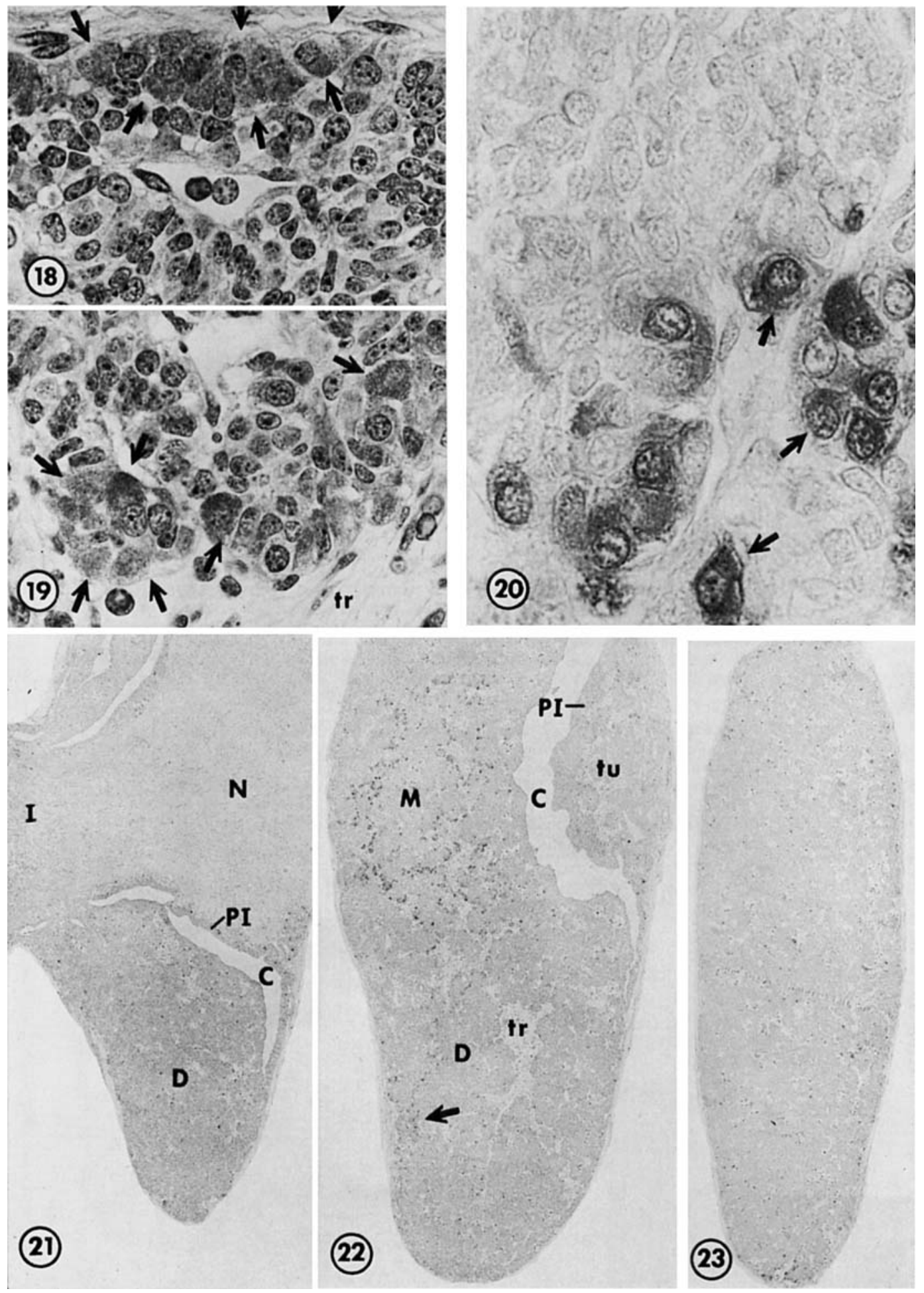
PLATE 5

EXPLANATION OF FIGURES

All illustrated sections were stained immunocytochemically.

24 Portion of a transverse section through the hypophysis of S-21 (23 weeks) showing that thyrotrophs (arrows) are located primarily in the anterior portion of the median zone (M). Anti-hTSH. $\times 34$.

25 Thyrotrophs in the median zone of S-21 illustrated in figure 24. AntihTSH. $\times 1000$.

26 A portion of the pars distalis from S-21 (23 weeks) showing the differentiation of gonadotrophs and thyrotrophs by double immunocytochemical staining - anti-hCG with diaminobenzidine, and anti-hTSH with a-naphthol followed by pyronin. Gonadotrophs (arrows) appeared gold while thyrotrophs (ts) appeared lavender. $\times 1000$.

27 Median sagittal section of S-14 (15.5 weeks) showing the distribution of thyrotrophs in the anterior median zone (arrows). They are absent from the pars tuberalis ( $T$ ), pars intermedia (PI), and the tubules (tu) associated with the pars intermedia. $\times 42$.

28 Sagittal section through the hypophysis of S-4 (11.5 weeks) showing the distribution of gonadotrophs (arrows). Compare with the distribution of thyrotrophs (fig. 27) at 15.5 weeks. At this time they appear chiefly in the anterior and superior portion of the median zone (arrows) of the pars distalis (D). Gonadotrophs are absent from the pars intermedia and tubules associated with it. Anti-hCG. $\times 42$. 
IMMUNOCYTOCHEMISTRY OF HUMAN FETAL HYPOPHYSIS

PLATE 5

Burton L. Baker and Robert B. Jaffe
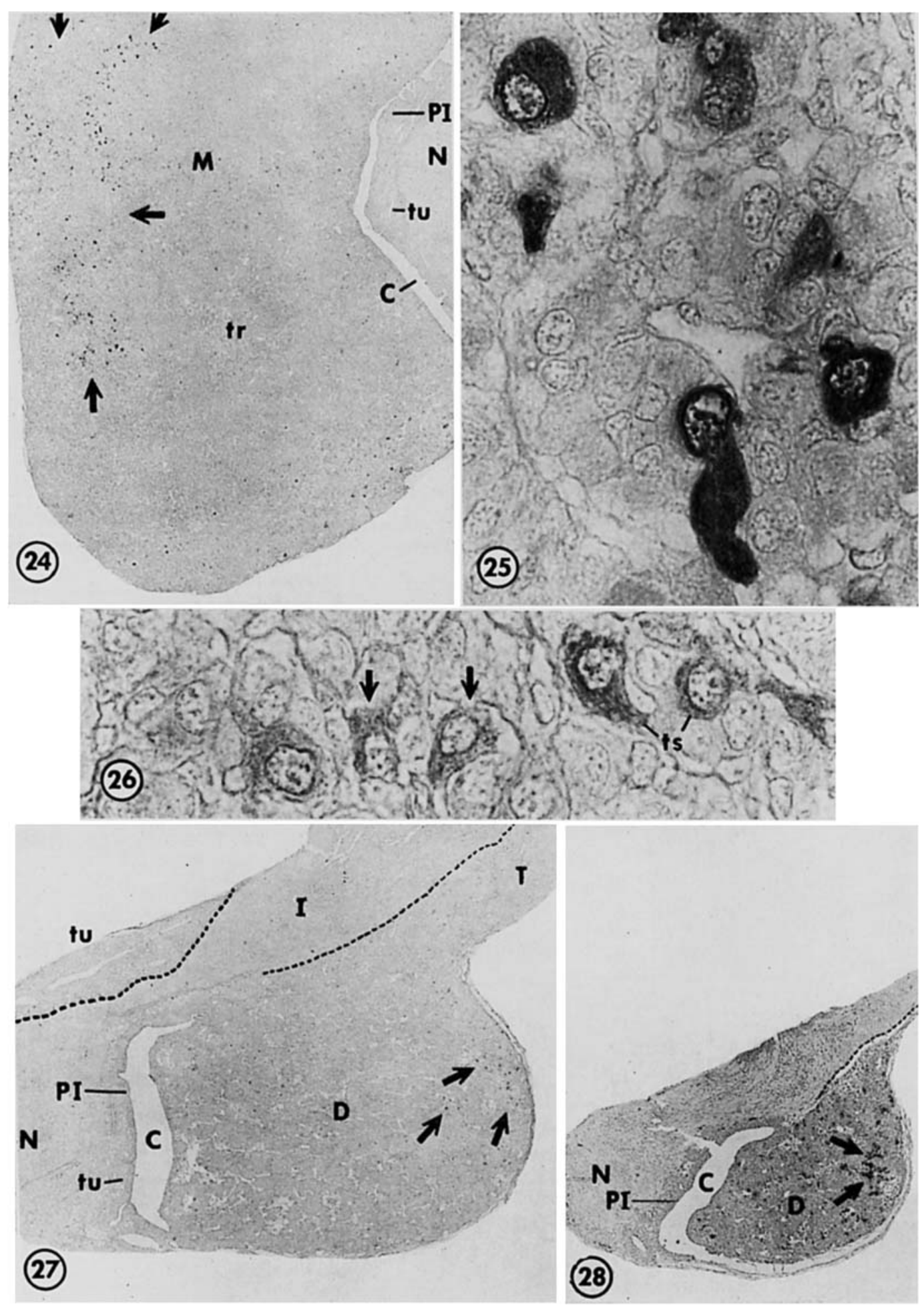
PLATE 6

EXPLANATION OF FIGURES

All illustrated sections were stained immunocytochemically,

29 A transverse section through the hypophysis of S-20 ( 16.5 weeks) at the level of the trabeculae (tr) to show the distribution of gonadotrophs. They are common throughout the pars distalis but are less numerous in the immediate vicinity of the trabeculae (tr) and in the anterolateral region (between the arrows). Gonadotrophs are absent from the pars intermedia (PI) and its associated tubules. Mason et al. ('69) technique. Anti-hCG. $\times 42$.

30 Section through the median pars intermedia and associated tubules of S-14 (15.5 weeks). Scattered cells (arrows) in the tubules and fewer in the pars intermedia contain melanotrophin. Anti-h $\beta$-MSH. $\times 400$.

31 A portion of the pars distalis of S-11 (14 weeks) showing gonadotrophs. Anti-hCG. $\times 400$.

32 The pars tuberalis ( $T$ ) of S-19 ( 16.5 weeks), extending far anteriorly beneath the median eminence, contains numerous gonadotrophic cells throughout its extent. The dotted line represents the boundary between the infundibulum and pars tuberalis. Anti-hCG. $\times 120$.

33 A section through the rostral portion of the pars tuberalis in S-15 ( 15.5 weeks) containing at least three gonadotrophic cells. Anti-hCG. $\times 1000$. 


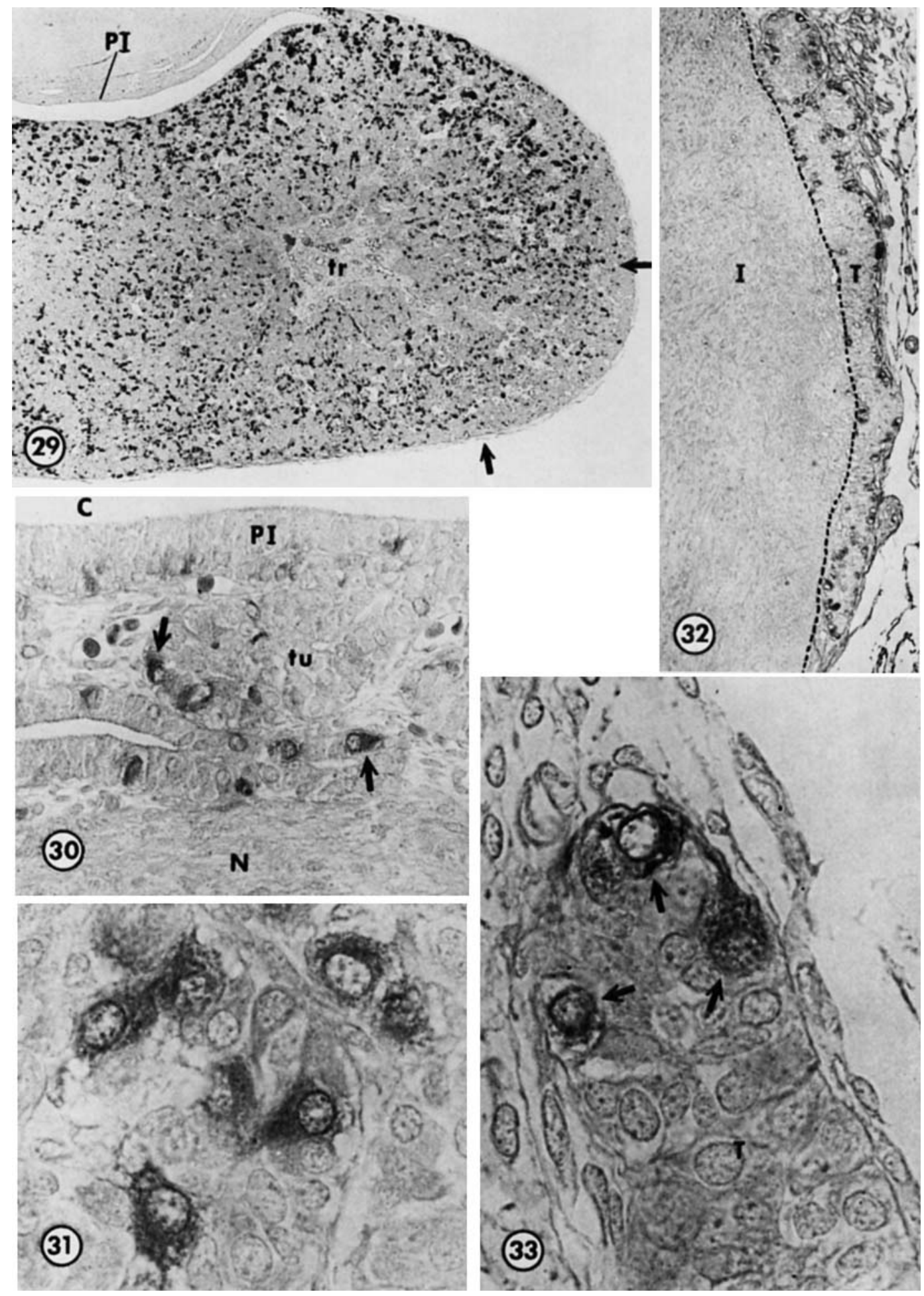

